\title{
The Sand Bar Formation and its Impact on the Mangrove Ecosystem: A Case Study of Kadalundi Estuary of Kadalundi River Basin in Kerala, India
}

\author{
$\mathrm{K}^{\mathrm{B}} \mathrm{BINDU}^{1 *}$ and G JAYAPAL ${ }^{2}$ \\ Department of Geography, Kannur University. \\ http://dx.doi.org/10.12944/CWE.11.1.08
}

(Received: March 11, 2016; Accepted: April 06, 2016)

\begin{abstract}
Mangrove ecosystems are prone to die due to both anthropogenic and natural effects. The present study is a case study of how the formation of sand bars affects the natural mangrove ecosystem and becoming a threat to its rich biodiversity of flora and fauna. The Kadalundi Vallikkunnu Community Reserve located in Kozhikode and Malappuram Districts in Kerala State is the first community reserve of Kerala, declared in 2007 which spread across $1.5 \mathrm{sq} . \mathrm{km}$. and this area includes Kadalundi bird sanctuary, mangroves and estuarine. These area mainly affected by numerous biotic interferences like over fishing, collection of oyster and mussels, mining of sand and lime and also retting of coconut. The formation of sand bars at the mouth of the river has resulted in the massive die back of the mangrove vegetation, especially that of Avicennia Marina which is one of the five species of mangroves found in the Kadalundi - Vallikunnu community reserve. The illegal utilization of land for coconut plantation, urbanization and dumping of urban waste near the mouth of the river had made the problem highly complicated. The present study highlights the need for urgent measures to be adopted from the authorities to ensure community participation for restoration of community reserve.
\end{abstract}

Keywords: Ecosystem, Mangroves, Kadalundi - Vallikunnu Community Reserve, Kadalundi River.

\section{INTRODUCTION}

The sand bars or shoals are a natural submerged ridge, bank or bar that consists of sand and other unconsolidated material and rises from the bed of a body of water near the surface. Often these rise up enough to the surface as to constitute a danger to an easy flow of the high tide and low tide water causing a threat to mangrove ecosystem. The formation of the sand bar is a more complex process and represents important morphological features of river estuaries. In the present study, an attempt is made to study the impact of sand bar formation near the estuary and its impact on the mangrove ecosystem based on a case study of Kadalundi - Vallikunnu Community Reserve, in Kerala. The Kadalundi - Vallikkunnu Community Reserve located in Kozhikode and Malappuram Districts in Kerala State is the first community reserve of Kerala ${ }^{1}$ declared in 2007 which spread across $1.5 \mathrm{sq} . \mathrm{km}$. This community reserve is situated at the estuary of Kadalundi River at a height of above 200 mean sea level. Figure 1 shows the location of Kadalundi bird sanctuary and it is a notable destination of migratory birds located between Tirur Taluk of Malappuram District and Kozhikode Taluk of Kozhikode District. Geomorphologically, the areas consist of coastal plains with sandy beaches, sand bars, dunes and inter-ridge depressions or basins. Kadalundi is characterized by the lens- shaped channel bars or sand islands and barrier ridges along with extensive mudflats which are exposed for the major part of the year forming suitable habitat for birds ${ }^{2}$.

The average annual rainfall of Kadalundi river basin is $3610 \mathrm{~mm}$, of which 60 percent is 
received during the south-west monsoon (June to September), 30 percent during the north-east monsoon and 10 percent during the summer season. The average annual surface water potential of the basin is estimated at $1829 \mathrm{~mm}^{3}$. The Kadalundi -Vallikkunnu community reserve is blessed with rich biodiversity in both flora and fauna. The natural environmental condition is very much favorable for setting a natural habitat for many rare and endangered flora and fauna ${ }^{[3]}$.

\section{MATERIALS AND METHODS}

The main objective of this study is to assess the impact of sand bar formation near the estuary and its impact on the mangrove ecosystem. A case study of Kadalundi - Vallikunnu community reserve, the first community reserve in Kerala, is carried out to assess the significance of mangrove conservation. The secondary data is used to assess the existing status of mangrove. The data pertaining to floristic analysis of all the true and associate mangrove plants was collected from Department of Botany, University of Calicut. The Google Earth Imageries of the year 2002 and 2014 are used to demarcate the evolutionary changes in land forms, especially on the formation and movement of sand bars, a spatial distribution of mangrove areas and to understand the spatial and temporal changes that happened due to the shifting sand bars near the Kadalundi estuary. The derived information is justified based on ground truth verification. The direct interview with the community reserve officials and local people dwelling in the study area was carried out to study the social attitudes towards the concept of community reserve.

\section{RESULTS AND DISCUSSION}

The present study reveals the morphological characteristics of sand bars formation and its movement during the period of 2002 to 2014. In the year $2004^{[5]}$, small patches of sand appeared on the outskirt of the mud flats formed near the Kadalundi railway bridge as shown by a red arrow in Figure 3. These sand bars expanded and formed like a hook shape near the mud flats as seen in the image of the year $2008^{[6]}$. In the year $2011^{[7]}$, a long stretch of the sand bar was developed which expanded and spread parallel to the mud flat under the Kadalundi railway bridge as seen in the image of the year $2012^{[8]}$. In the image of $2014^{[9]}$, this long stretch of the sand bar is found close to the patches of mangroves on the mud flats below Kadalundi railway bridge. These series of images as shown in Figure 3 not only depicts the morphological characteristics of sand bars formed in the Kadalundi estuary but also their temporal and spatial changes occurred in the span of twelve years. The image reveals that the sand bars are moving and are not permanent in a place. Figure 4 shows that approximately 56 meters of the sand bar was found shifted towards the terrestrial mangrove area. The formation of new sand bars of $1332 \mathrm{sq}$. $\mathrm{km}$ was found near the mouth of the estuary.

\section{Formation of Sand Bars and Degradation of Mangroves}

Based on the analysis of the satellite imageries from Google Earth and field survey, the present study reveals that there are three species of true mangrove plants, five species of mangrove associates and two grass plants near the Kadalundi estuary. The dominant species in the study area is Avicennia mariana followed by Acanthus ilicifolius. Table $1^{[10]}$ list out the major five species of mangroves in the Kadalundi estuary.

Among these listed mangrove species the Acanthus ilicifolius ( Linn. )Figure 5 (a) and Avicennia marina (Forsk.) Vierh. Figure 5 (b) are marked as endangered species. The Avicennia marina is completely disappeared from the study area. The accumulation of sand near the breathing root of mangroves fills the breathing holes and result in its deterioration. The seed and seedlings of the plant were found settled on the sand bars without getting flooded away by the tidal currents.

The sand bars due to its instable nature and in and out flow of water shifts its place and leads to the unstable flats where roots of young mangrove plants cannot flourish and causes dieback of mangroves in these areas. The long stretch of sand bars, block the free in and out flow of fresh and salt water because of which mangroves are slowly deteriorating as shown in Figure 5 (c). The establishment of sea grasses as shown in Figure 5 (d) on the sand bar restrict the further growth of the mangroves as these are plants which require less water and doesn't require a marshy area to 


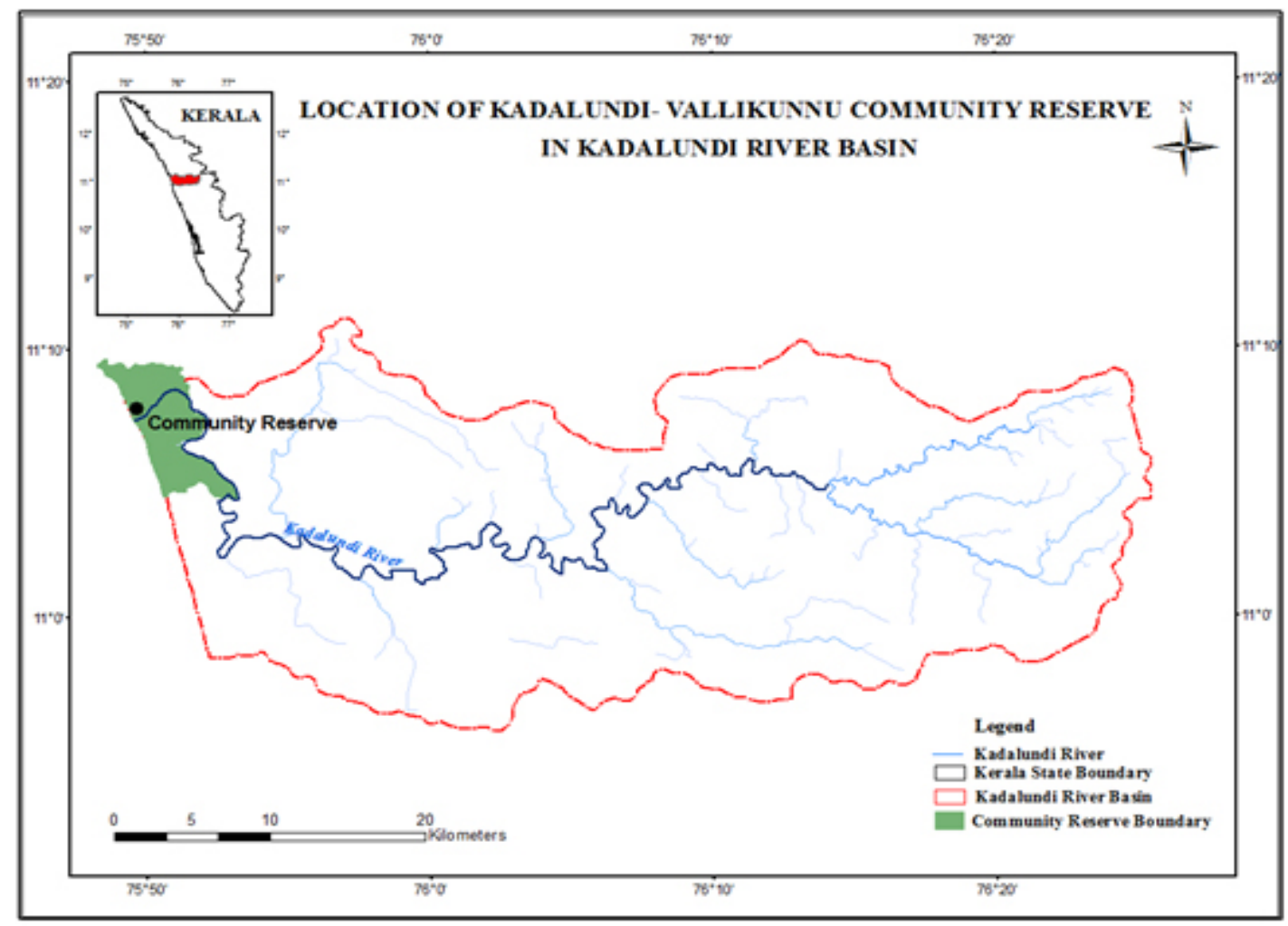

Fig 1: Location Map of Kadalundi - Vallikunnu Community Reserve in Kadalundi River Basin

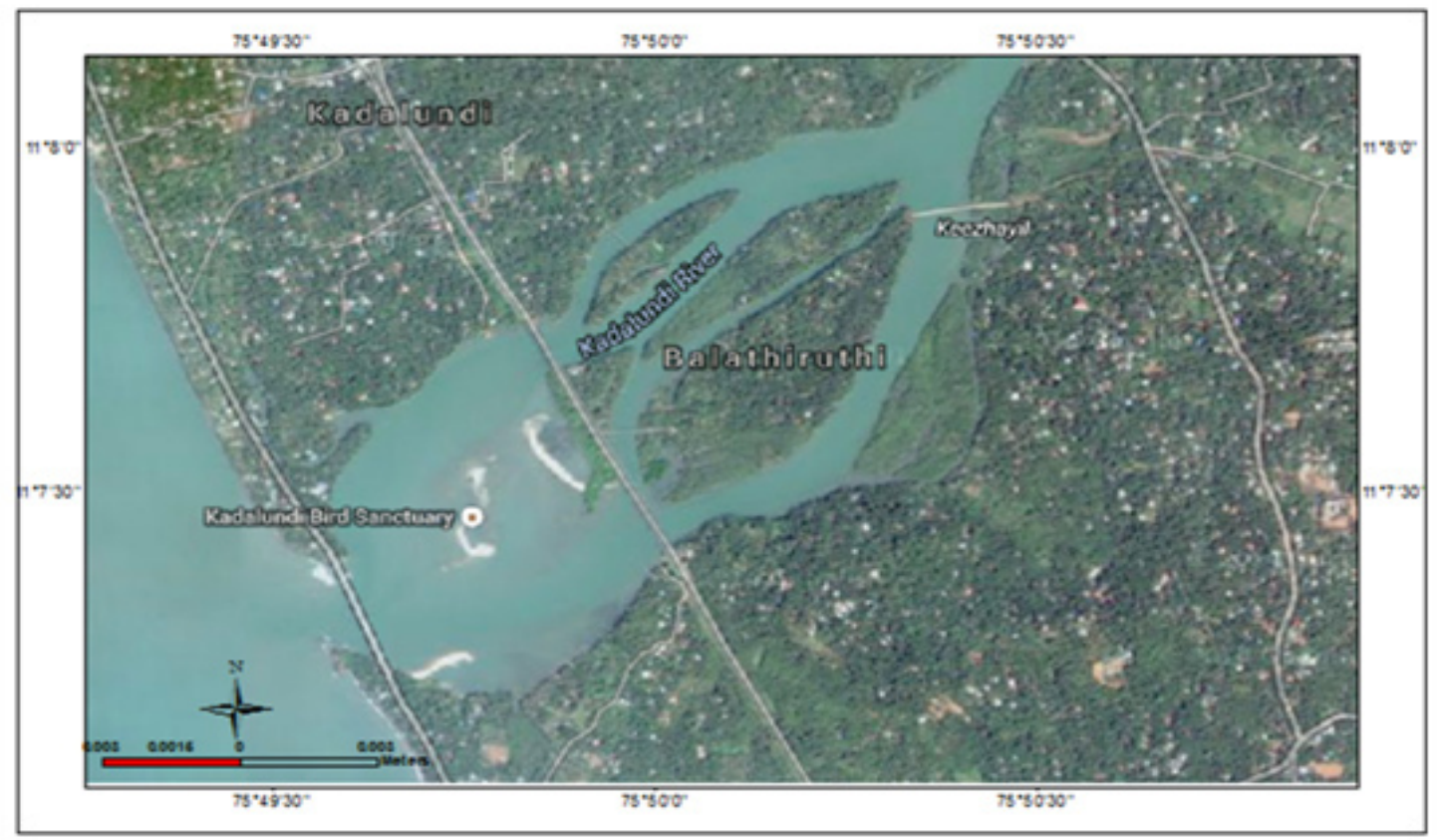

Fig 2: Location Map of Kadalundi Bird Sanctuary in Kadalundi Estuary ${ }^{4}$ 
survive. Due to mass dieback of mangroves many fauna including small fish, sea sells, crabs as shown in Figure 5 (e) are losing their habitat as they can only survive under this mangrove ecosystem. The plastic wastes settled along the sand bars and near

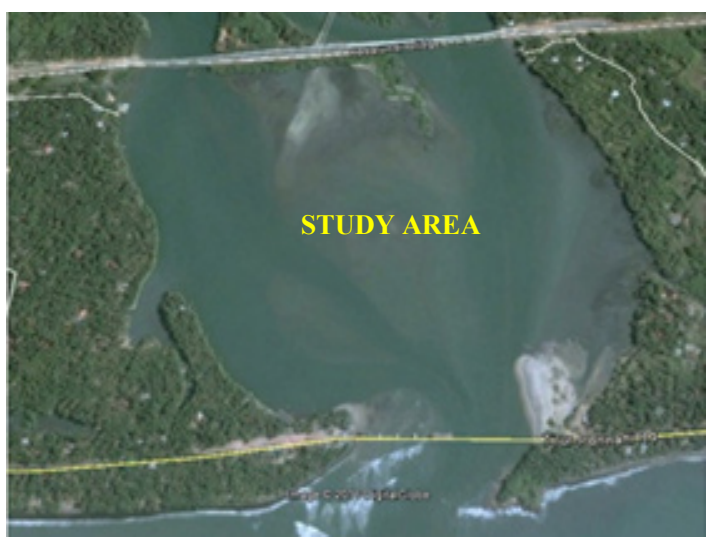

2002

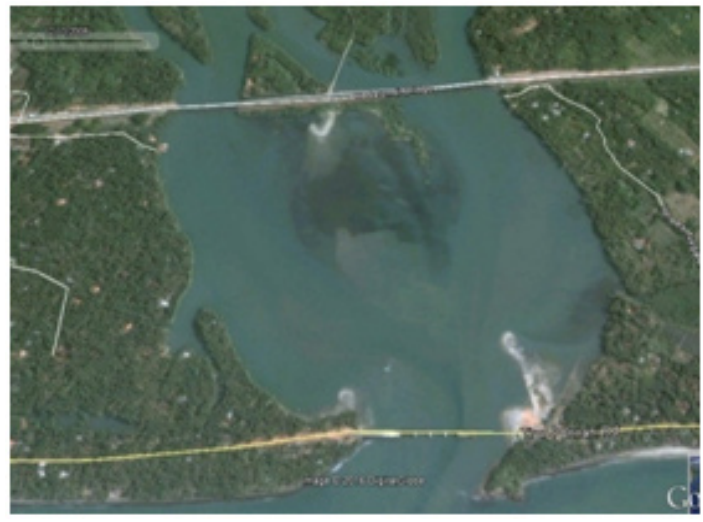

$2008^{[6]}$

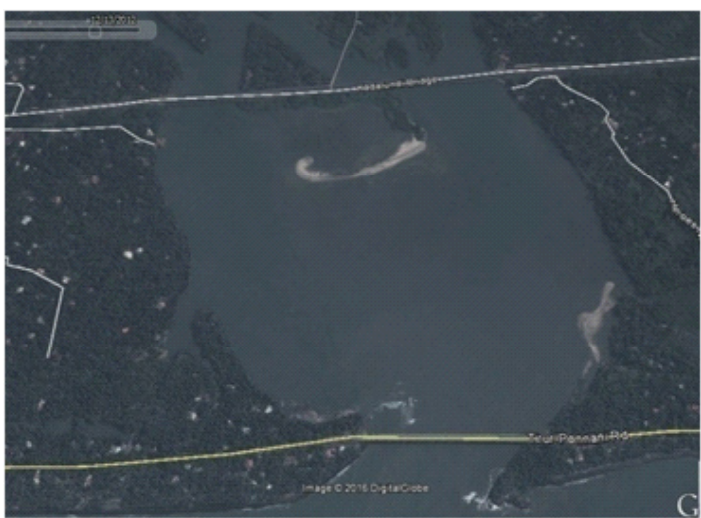

$2012^{[8]}$ the roots of mangroves are causing land and water pollution, disturbing the associated flora and fauna. The Figure 5 (f) shows the plastic wastes dumped by the river water as it flows along the sand bars during low tide. The reasons for the formation of the sand

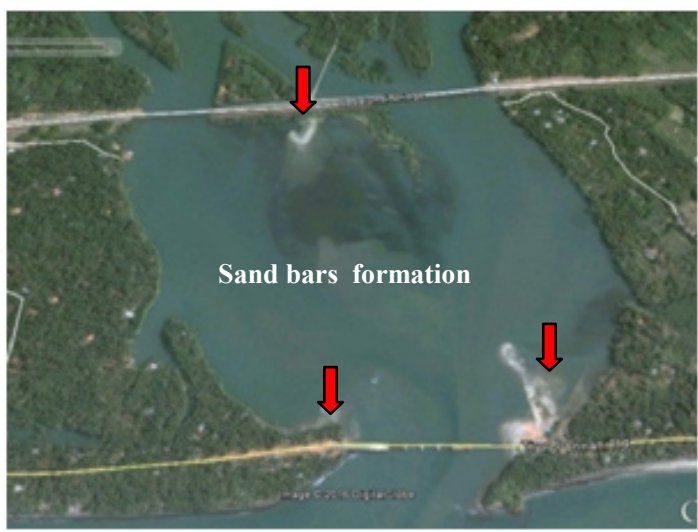

$2004^{[5]}$

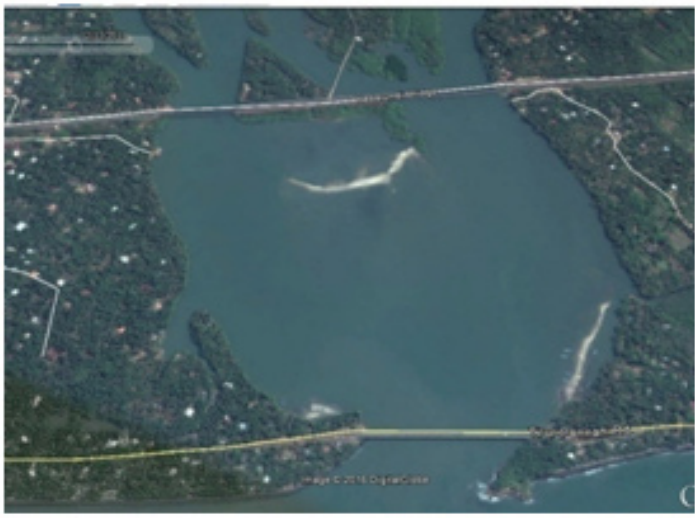

$2011^{[7]}$

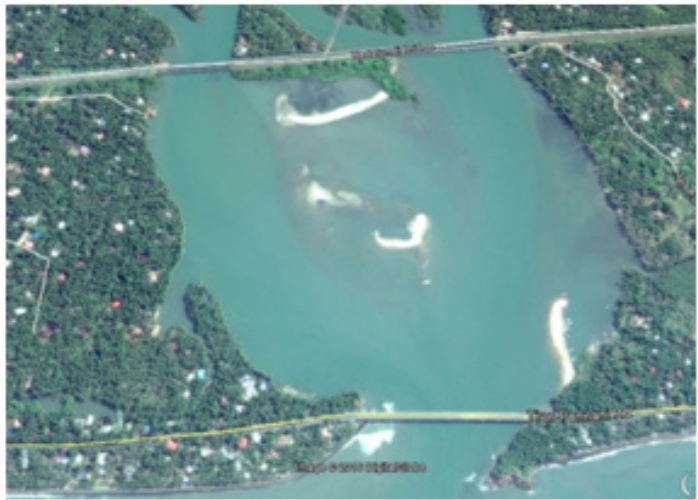

$2014^{[9]}$

Fig. 3: Temporal and Spatial Formation and Changes of Sand Bars from the year 2002 - 2014 
bar may be many but still more study is to be done in this regard. The washed away sand from the salt water intrusion bund on the upper streams of the kadalundi river near to the kadalundi estuary gets accumulated in this area. This may be due to lack of proper flow of water from the kadalundi river to the sea. Due to the construction of the Tirur Ponnani road at the opening of estuary the flow from sea to the river side is obstructed and due to low flow, the sand particles carried by the waves are deposited as sand bars. Construction of boat jetties near the mouth of the estuaries also block the sand sediments from being washed away. Hence, if this condition prevails, both these natural and anthropogenic activities will lead to complete elimination of mangrove vegetation from Kadalundi-Vallikkunnu mangrove ecosystem in future.

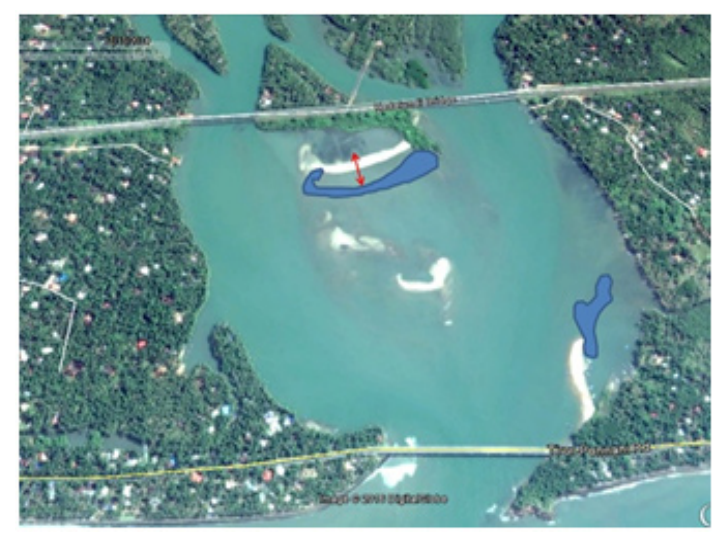

Fig. 4: Shift of Sand Bars from the year 2013 to 2014

\section{DISCUSSION}

The present study clearly illustrates the fact that the formation of sand bars is a major threat to mangrove ecosystem in Kadalundi - Vallikkunnu Community Reserve, the first community reserve for protecting mangroves in Kerala. After the implementation of community reserve, in spite of many administrative constrains, there was a large-scale increase in the total extent of mangrove areas ${ }^{[11]}$. Due to its peculiar reproductive system, the mangrove grows itself without much care and is found luxuriantly developed in the reserve area where the human influence is strictly restricted ${ }^{[12]}$. But the natural causes such as the formation of sand bars, filling of existing mud flats with the sand deposits are equally a matter of concern for conserving mangroves from deterioration. The natural causes are often ignored by the people as they always act as a silent killer. Thus, a proper research in order to understand the root cause of sand bar accumulation and to avoid the deterioration of existing mangrove swamps is the need of the hour. This will to a great extent preserve the existing mangroves and stop the deterioration of mangrove ecosystem in Kadalundi - Vallikunnu Community reserve.

\section{ACKNOWLEDGMENT}

Authors are thankful to the Forest Division Office, Kadalundi, and Kozhikode for their kind support to carry out the field work. Special thanks to Mr. Kallanathan P, Community Reserve Committee

Table1: ${ }^{[10]}$ List of Major Five Species of Mangroves

\begin{tabular}{llll}
\hline SI. No & Species Name & Status & Family \\
\hline 1 & Acanthus ilicifolius (Linn.) & TM & Acanthaceae \\
2 & Avicennia marina (Forsk.) Vierh. & TM & Avicenniaceae \\
3 & Clerodendrum inerme (L.) Gaertn & MA & Verbenaceae \\
4 & Caesalpinia crista L & MA & Caesalpiniaceae \\
5 & Derris trifoliate Lour & MA & Fabaceae \\
6 & Ipomea pes-caprae (L.) R.Br & MA & Convolvulaceae \\
7 & Rhizophora mucronata (Lam.) & TM & Rhizophoraceae \\
8 & Mariscus javanicus (Houtt.) Merr and Metcalf & & Cyperaceae \\
9 & Pennisetum pedicellatum Trin & & Poaceae \\
\hline
\end{tabular}

TM - True Mangrove, MA - Mangrove Associates 


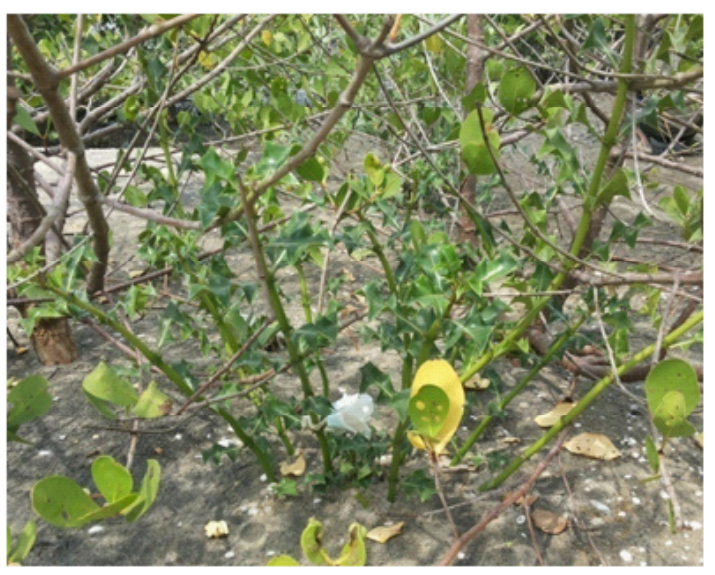

Fig 5 (a)

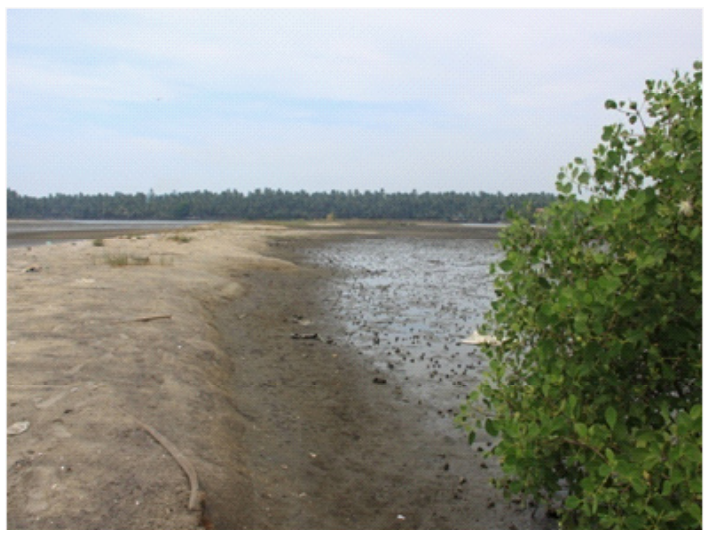

Fig 5 (c)

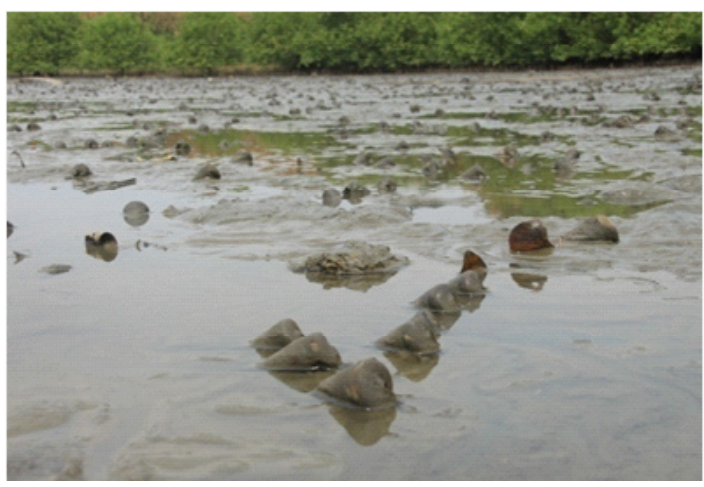

Fig $5(e)$

Member and Dr. Sreejith Kanholi, Museum Curator, Department of Zoology, the University of Calicut for conducting the field survey and taking photographs.

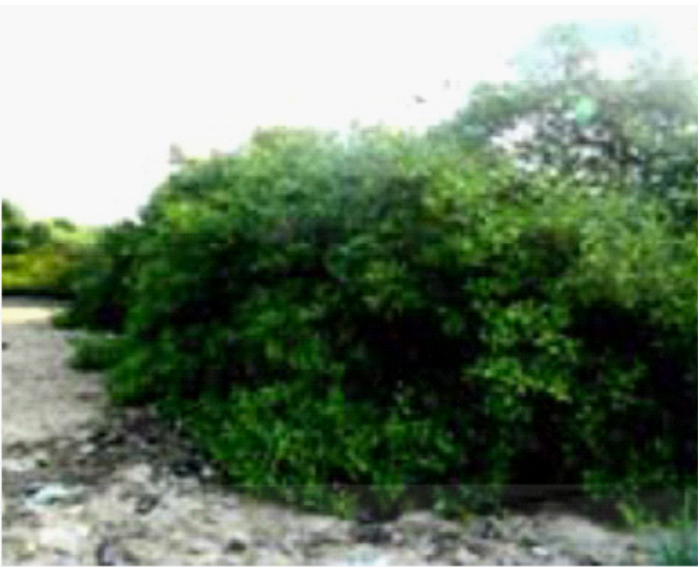

Fig 5 (b)

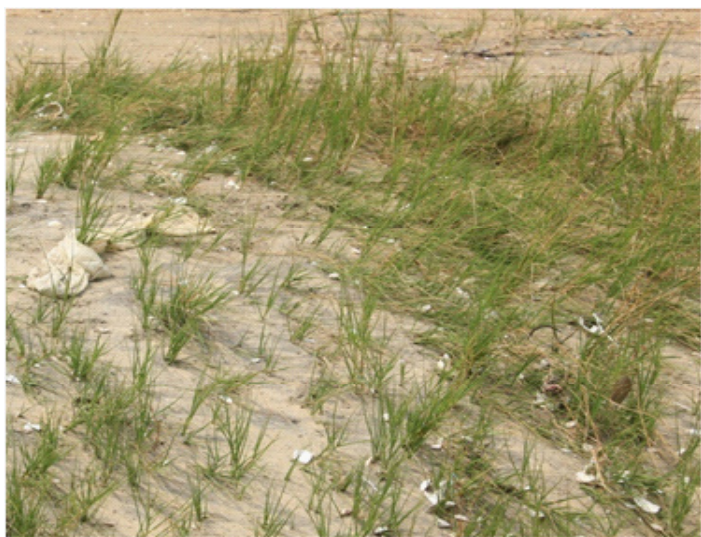

Fig 5 (d)

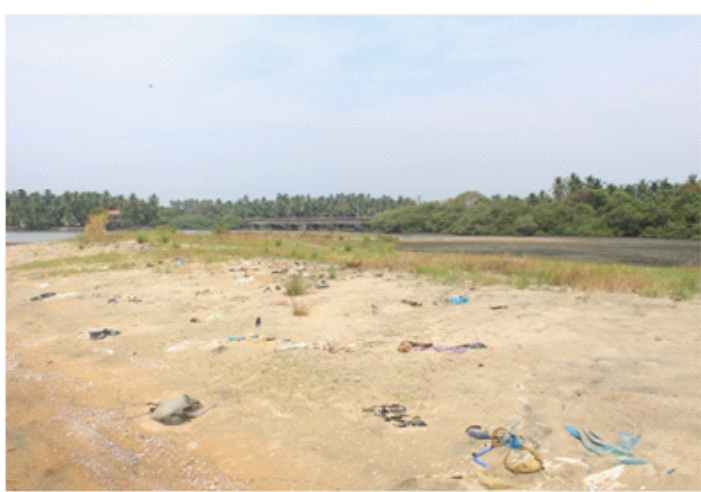

Fig 5 (f)

Thanks to the Google Earth Company ${ }^{[4]}$ for providing freely available images for the research purpose. 


\section{REFERENCES}

1. Rahees, N., Kiran, M and Vishal, V., Phytosociological Analysis of Mangrove Forest at Kadalundi - Vallikunnu Community Reserve, Kerala. International journal of Science, Environment and Technology, ISSN 2278-3687 (O), 3(6), 2154 - 2159 (2014)

2. Aarif, K.M., Prasadan, P.K., \& Babu, S., Conservation Significance of the KadalundiVallikkunnu community Reserve. Current Science, 101(6): 717-718. (2011)

3. Nair, R. M., Kadalundi-Vallikunnu Community Reserve Rich in Flora, Fauna. http://www.hindu. com/2007/10/17/ stories/2007101753200500. htm (2007).

4. Google earth V 6.2.9200.0. (December 14, 2015). Kadalundi Estuary, Malappuram, kerala, India. $11^{\circ} 7^{\prime} 34.82^{\prime \prime} \mathrm{N}, 75^{\circ} 49^{\prime} 44.62^{\prime \prime} \mathrm{E}$, eye alt $6275 \mathrm{ft}$. Digital globe 2016. http://www. earth.google.com (March 21, 2012).

5. Google earth V 6.2.9200.0. (December 13, 2002). Kadalundi Estuary, Malappuram, kerala, India. $11^{\circ} 7^{\prime} 34.82^{\prime \prime} \mathrm{N}, 7^{\circ} 49^{\prime} 44.62^{\prime \prime} \mathrm{E}$, eye alt $6275 \mathrm{ft}$. Digital globe 2016. http://www. earth.google.com (March 21, 2012).

6. Google earth V 6.2.9200.0. (December 13, 2008). Kadalundi Estuary, Malappuram, kerala, India. $11^{\circ} 7^{\prime} 34.82^{\prime \prime} \mathrm{N}, 75^{\circ} 49^{\prime} 44.62^{\prime \prime} \mathrm{E}$, eye alt $6275 \mathrm{ft}$. Digital globe 2016. http://www. earth.google.com (March 21, 2012).
7. Google earth V 6.2.9200.0. (December 13, 2011). Kadalundi Estuary, Malappuram, kerala, India. $11^{\circ} 7^{\prime} 34.82^{\prime \prime} \mathrm{N}, 75^{\circ} 49^{\prime} 44.62^{\prime \prime} \mathrm{E}$, eye alt $6275 \mathrm{ft}$. Digital globe 2016. http://www. earth.google.com (March 21, 2012).

8. Google earth V 6.2.9200.0. (December 13, 2013). Kadalundi Estuary, Malappuram, kerala, India. $11^{\circ} 7^{\prime} 34.82^{\prime \prime} \mathrm{N}, 75^{\circ} 49^{\prime} 44.62^{\prime \prime} \mathrm{E}$, eye alt $6275 \mathrm{ft}$. Digital globe 2016. http://www. earth.google.com (March 21, 2012).

9. Google earth V 6.2.9200.0. (December 13, 2014). Kadalundi Estuary, Malappuram, kerala, India. $11^{\circ} 7{ }^{\prime} 34.82^{\prime \prime} \mathrm{N}, 75^{\circ} 49^{\prime} 44.62^{\prime \prime} \mathrm{E}$, eye alt $6275 \mathrm{ft}$. Digital globe 2016. http://www. earth.google.com (March 21, 2012).

10. Syamjith, P. K., \& Ramani, N., Is Sand Bar Formation a Major Threat to Mangrove Ecosystem? International journal of Science and Research (IJSR), ISSN 2319-7064, Vol. 3 Issue 11, 2005 - 2011 ( November 2014)

11. Arun Kanagavel., Rajeev Raghavan., Cynthia Sinclair \& Aditya Prithvi A Status Survey of Existing Community and Conservation Reserves in South India. WILDE Coimbatore (2013).

12. Basha C S., Distribution of Mangroves in Kerala. Indian Forester 117 (6), 439-44 (1991). 